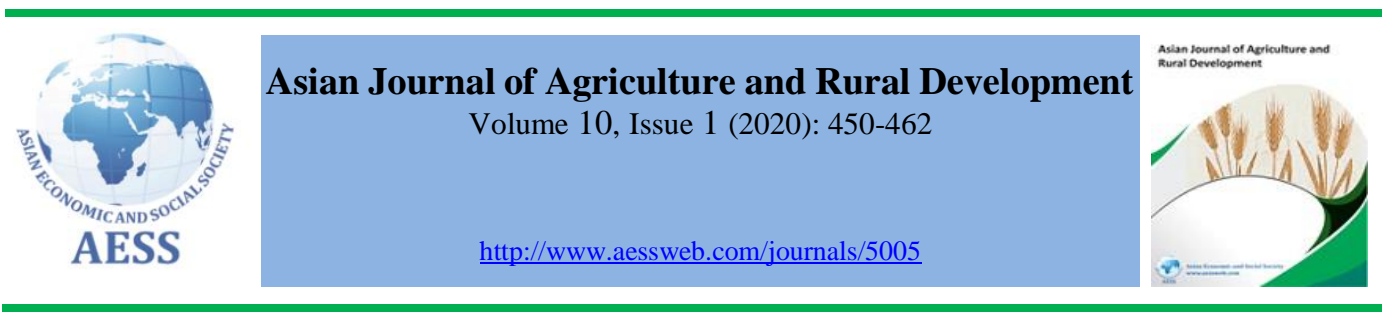

\title{
DOES DIGITAL MARKETING ENHANCE RURAL AGRICULTURAL TRANSFORMATION IN NIGERIA? AN EMPIRICAL INVESTIGATION
}

Evelyn Nwamaka Department of Economics, Faculty of Arts, Management \& Social Ogbeide-Osaretin ${ }^{\text {a }}$, Sciences, Edo University Iyamho, Edo State, Nigeria

Oseremen Ebhote $^{\mathbf{b}}{ }^{\mathrm{b}}$ Department of Business Administration, Faculty of Arts, Management \& Social Sciences, Edo University Iyamho, Edo State, Nigeria

\section{\iyokoevelyn@gmail.com (Corresponding author)}

\section{ARTICLE HISTORY: \\ Received: 06-Mar-2020 \\ Accepted: 16-May-2020 \\ Online Available: 22-Jun- 2020}

\section{Keywords:}

Agriculture,

Digital,

Marketing,

Rural Transformation

\begin{abstract}
The rural transformation has been noted as an important national policy goal. This requires among other things the use of recent technology to enhance agricultural production. This study examined the role of digital marketing in rural transformation. The objective of the study was to determine the impact of digital marketing using ICT devices on Nigeria's rural transformation. Nigeria's time-series data on agricultural value-added was used as a measure of rural transformation on some measures of digital marketing (the percentage of internet users and the proportion of mobile users). Rainfall and some control variables were also included over the time from 1995 to 2018. Ordinary least square estimation method was employed in a linear model as no cointegration was found among the variables, proved by the bound testing result. The outcome showed that digital marketing is positively and substantially related to rural transformation. We hence, advocate that digital marketing be strongly encouraged by providing the needed infrastructure facilities as well as increasing the availability of education in the rural areas among others.
\end{abstract}

\section{Contribution/ Originality}

This present study contributes to the role of digital marketing towards agricultural production which has received some literature by employing econometric estimation techniques contrary to most previous studies that employed survey methods. It also took a step by including rainfall in the model which has not been captured before now.

DOI: 10.18488/journal.1005/2020.10.1/1005.1.450.462

ISSN (P): 2304-1455/ISSN (E):2224-4433

How to cite: Evelyn Nwamaka Ogbeide-Osaretin and Oseremen Ebhote (2020). Does digital marketing enhance rural agricultural transformation in Nigeria? An empirical investigation. Asian Journal of Agriculture and Rural Development, 10(1), 450-462.

(c) 2020 Asian Economic and Social Society. All rights reserved. 


\section{INTRODUCTION}

Agriculture plays a fundamental role in the Nigerian economy funding the maximum share to the nation's gross domestic production (GDP). It is an enormous potential to shoot growth, and advance income. For instance, in 2017, agriculture guaranteed about $20.85 \%$ to Nigeria's GDP, $22.32 \%$ arise from industry, and 55.8\% stems from the services sector. In 2018, agriculture contributed $22.86 \%$ to Nigeria's GDP, industries $23.18 \%$, and services $53.97 \%$. The oil sector contributed $8.55 \%$ of GDP and the non-oil sector accounted for $91.45 \%$ and in 2019 , the sector provided $21.91 \%$ to real GDP, greater than it impacts in the first quarter of $201821.66 \%$ (National Bureau Statistics, 2017, 2018, 2019).

Despite these indices, the agricultural performance in Nigeria remains insufficient and undeniably far less than its capacities. Agricultural practice is the mainstay of rural dwellers in Nigeria with most of the countryside population reliant on it. Sector encounters glitches in enhancing production amidst deteriorating natural resources indispensable for production. The swelling entreaty for agricultural products gives projections for farmers to sustain their production and possibly boost their income. Nigerian governments in the past have attempted to add their slice to appeal and enhance agricultural production in Nigeria by coming up with numerous projects targeted at expanding the sector between 1962 to date. This development is evident in the following areas; the introduction of state-of-the-art agricultural techniques utilizing farm settlements, accommodating plantations, provision of modern farm tools, and a significantly providing vibrant agricultural extension services. Others include the National Accelerated Food Production Programme NAFPP in 1972, the advent of Operation Feed the Nation (OFN) in 1977, and the Green Revolution Programme invented in 1980. The Agricultural Development projects financed by World Bank, Agricultural Extension and Research Institutes of the mid-80s. All of the above initiated to facilitate food and cash crop production in Nigeria (National Agriculture Survey, 2001). Sadly, however, studies revealed that these programs initiated by the government at one point in time or the other have not copiously accomplished the purpose for which it was established.

In 2018, the World Bank collection of development indicators recorded that about $49.66 \%$ of the Nigerian population lives in rural areas. However, affordability and long-range coverage of most cell phone providers have made it possible for nearly all her rural dwellers to be cell phone owners (Alliance for affordability internet, 2019; Trading Economics, 2020). In the same manner, more than 100 million citizens in Nigeria have access to the internet, with over 250,000 newfangled subscribers logging onto the internet in the later part of 2019 (Russon, 2020). With this development, Nigeria has witnessed a radical advancement in the information communication technology sector. Within the last few years, Nigeria has seen incredible growth in ICT resources and facilities, and about twenty- eight million Nigerians now have access to the internet and mobile phone devices (Agwu, 2012). Telecommunication and information technology contributed $77 \%$ of the entire sector's contribution to the GDP. Overall, the mobile telecommunication sub-sector contributed $7.4 \%$ to the country's GDP in 2018 , compared to $5.5 \%$ in 2017 . Now, $44 \%$ of mobile subscribers in Nigeria are using 3G and 4\% are using 4G technology (Mobile Report, 2019). Abdulsalam et al. (2008) opine that "Information and communication technology plays a significant function in solving agricultural related problems oscillating from site selection, sale of farm produces in many parts of the world, they, however, noted that the use of ICT and online marketing of agricultural products specifically in Nigeria is still at infancy. Therefore, a gap exists in the research in this area of rural agricultural transformation through online marketing strategies in Nigeria. This is however amazing when one contemplates the relevance of agriculture to the nation's economy because most Nigerian are agrarian. Aside from the oil sector, the agricultural sector is likened to being the most influential instrument of growth essential for economic development and the transformation of the rural areas in the country. This study, therefore, aims to 
examine the rural agricultural transformation using online marketing strategies in Nigeria. Therefore, the qualitative method will be employed, and this entails the use of questionnaires to collect needed data on the significance of rural agricultural transformation with the aid of online marketing strategies. The broad objective of this study is to examine rural agricultural transformation via digital marketing strategies in Nigeria.

\section{LITERATURE REVIEW}

\subsection{Conceptual literature}

Nwobi (2007) opines that rural development can be seen as the development of the moral, social, political and economic potentialities of rural communities to enhance their self-reliance through the provision of appropriate infrastructures such as pipe-borne water, electricity, good roads, and small scale industries, increase their political consciousness and participation, promote their moral and social well-being which will result in tolerance, good discipline, justice, fairness, kindness, love, and peace. Similarly, Filani (2000) defined rural development as the process of making life more satisfying and fulfilling for millions of people who live in rural areas. Rural development provides rural dwellers with the opportunities for gainful employment as well as the expansion of social services which could enhance the welfare and security of rural people". The definitions above lead us to the features of rural development which comprises of enhancing the standard of living of the population which encompasses the mobilization and apportionment of funds to reach desirable equilibrium overtime between the wellbeing and fruitful services obtainable to rural subsistence population, mass involvement which necessitates that resources be shared to low-income areas and classes and that the productive services reach them, and making the process self-sustaining which requires the development of suitable skills and implementing capacity and the existence of institutions at the local, regional and national levels to ensure actual supplementary financial and human resources for the sustained development of the subsistence sector. IFAD (2016) present the following among others as numerous countryside modification scheme: Dearth and inequality decline, ensuring victual guarantee and quickening agricultural growth, provision of good careers and creating an opportunity for economic autonomy in the villages, stir the development of villages and intermediate communities, overseeing complex and delicate matters of relocation from villages to cities, provision of infrastructure facilities like good and sound education for the rural dwellers, provision of better health facilities, provision of good housing, availability of potable water, provision of electricity, good transportation, and communications network, offering extensive access to well-organized and practicable financial facilities as well as encouraging invention, findings, and development aimed at meeting the requirements of citizens residing in villages, manufacturers, and multinationals.

Challenges faced by rural communities according to OECD (2010) includes; rural areas are remote communities far from main cities with difficulty inaccessibility, attaining standard rural-urban linkages is quite tasking financially; rural areas are usually less populated compared to cities so there is difficulty achieving economies of scale for the production of goods and services; infrastructure amenities is low or in some cases not available; high amount of labour drain, unskilled laborers and low paying jobs; human capabilities and institutional capabilities are limited; they are characterized by issues of migration and social element.

\subsection{Digital marketing}

Digital marketing in Nigeria has formed an integral aspect of marketing in the 21 st century. It has acquired maximum acknowledgment over the past years since it was incorporated into the marketing system, with various search engines and discoveries accompanied by social media marketing. These have made online marketing an arduous and encouraging one. Online marketing is also referred to as e-marketing and internet marketing. It is the application of marketing principles and techniques through electronic media and more specifically the internet. Online 
marketing describes an organization's effort to inform buyers to communicate, promote, and sell its products and services over the internet (Igbenedion and Egwuelu, 2016).

The role of digital marketing cannot be overemphasized, these roles are as follows: creating customers services through chatting; giving intermediate advice to customers about products for sales on their websites; training customers on the use of their websites to avoid frustrations that come due to lack of knowledge on how to access their website; providing online product categories that money can be spent or to buy; making buyers and sellers online; taking orders online - the essence of these is to make prices more transparent and gain a better picture of their true value and build customer relationship Gives firsthand information on new products (Igbenedion and Egwuelu, 2016).

\subsection{Digital marketing and agricultural rural transformation}

Food and Agriculture Organization noted that with the global population attaining 9.1 billion in 2050, accommodating this mounting population, world food production has to be increased tremendously by about $70 \%$. The Africa population is expected to increase to about 2billion by 2050 . Productivity in agriculture is expected to increase faster than the intercontinental average to circumvent mass famishment. Key global companies have made attempts to introduce digitalizing of African agriculture by launching payment systems and digital insurance to help the farmers' survival (Ndubuisi, 2017).

Nikola et al. (2019) opined that reading ability, digital skills, and the accessibility of competence influence the use of digital transformations. Today, almost half of the world population has access to the internet, this is unreasoningly in developed nations like Nigeria and other African nations. In rural communities, where education and literacy rates are significantly low, mobile phone technology tends to be used primarily for communication and social media. This offers a great difficulty for the introduction of digital agriculture applications which necessitates more forwardthinking digital skills. Low global smartphone ownership in rural communities in addition to the high cost of internet and insufficient system coverage also presents difficulties in the use of mobile agricultural applications and diminish the chance of using social networks like Facebook to streamline agricultural support and information movements between farmers. Such availability of information could back farmers to make better farming decisions which could enhance increased yields, lessen environmental influences, and upgrade livelihoods.

Singh et al. (2015) stated that the Agriculture Information System (AIS) is a computer-based information system that encompasses all the interconnected information which could help farmers in handling information and policy decision making. The online strategies hat aid accelerating farming activities covered applications like radio, television, cellular phones, computers, tablets and networking, hardware and software, satellite systems (Munyua and Adera, 2009; Pande and Deshmukh, 2015). In the same vein, (Yimer, 2015; Munyua and Adera, 2009) reports that radio is virtually utilized to communicate with users on agricultural subjects, including novel and upgraded farming methods, production management, and market information. This shows that farmers may take benefit from using radio in the absence of technology rural farmers. The Internet and webbased applications are lengthily used in distribution and spreading of agricultural awareness, marketing of goods and services. The study conducted by (Ramli et al., 2015) has revealed the proposition that online campaigns are an effective answer to complications that effect the advancement of the agricultural industry, such as frail marketing associations, poor information management, truncated productivity, low income and lack of diversity. Singh et al. (2015) noted that the relevance of online marketing in agriculture can be seen in the area of distributing agricultural information systems to farmers at all levels. 
Portable phones are in the front-line of the digitalization of farming activities. As for 2011, several studies show that 6 billion active subscriptions, SIM's are projected to be engaged universally (Wireless Intelligence, 2011). Portable phone permeation in the unindustrialized world currently surpasses two subscriptions for every three individuals, motivated by intensifying links in Asia and Africa. Proficiency to acquire cheap phones together with the widening communications set-up has made most African countries especially Nigeria to have more than $90 \%$ of her citizens possess mobile handsets due to the availability of mobile signals in local communities. This swift development comes from upholding procedures that certify rivalry in the communications division along with increasing exigencies for mobile handsets. Olaifa and Oyeniyi (2014) noted that 91.4 percent of the local agriculturalists in Kwara State desire seeking info from administrative authorities through messages on their numerous happening their devices. This is because statistics from the phone are quite cooler, inexpensive, and suitable for both the source and the recipient. The spread and ability to acquire the internet are on the rise specifically in developing nations.

\subsection{Empirical literature}

Tolulope et al. (2015) on the application of ICT to agriculture as root to unemployment reduction in Nigeria focused on the significance of agriculture in the nation and the essence of utilizing info and communication technology in the sector as a cure to the incessant joblessness faced by Nigerians. They used qualitative techniques by interviewing groups and individuals on a cluster of students, farmers, and traders in Ogun and Lagos States of Nigeria. The outcome found that though the Nigerian government is encumbered with the responsibility of development which includes agriculture, the private sector should complement government effort by investing in ICT in the sector to boost and encourage the youth to see the agricultural sector as a viable sector.

Abdulrahman et al. (2017) investigated the opportunities and challenges facing the developing countries as it applies to ICT to examine the relationship between ICT and agriculture vis-à-vis the opportunities and problems of the sector. Results revealed that increasing market events, exchanging relevant info, profit gain, steering research, and managing economic growth for selfreliance are among the likely paybacks of information communication technology in the agricultural sector. Similarly, the study acknowledged insufficient information communication technology facilities, a deficiency of personnel, unsatisfactory infrastructure, synchronization of knowledge and language, power supply, and farmers' view are the factors that constrain the complete implementation of information communication technology in the sector in Nigeria.

Mbagwu et al. (2018) looked at the problems of meeting the information requirements of agriculturists in the villages via internet services. The rationale of the research was to detect the numerous encounters connected with meeting information requirements of rural farmers through online-based services with a specific focus on developing countries. The finding of the study shows that forming an online farmers' dialogue opportunity, establishing ICT and agricultural information literacy, adequate research to know the need of the rural farmers, repackaging of information using social media rostrum was among the major recommendation for the study.

Landes and Burfisher (2009) examined the growth and equity effects of agricultural marketing efficiency gains in India. In their study, they assert that agriculture is the utmost font of employment in India, and food quaffs fractional consumer expenditures. The researchers adopted a quantifiable general equilibrium model with agricultural products and households disaggregated by rural, urban, and income class to study the likely effects of restructurings that accomplish productivity gains in agricultural marketing and lessen agricultural input subsidies and import tariffs. More efficient agricultural marketing produces economy inclusive gains in output and wages, increases agricultural producer prices, decreases consumer food prices, and surges private consumption, predominantly by low-income households. 
Seyed et al. (2016) surveyed the adoption of agricultural e-marketing using the planned behavior theory (TPB). Using primary data from 146 professionals drawn from public and private sectors, findings showed that the model explained about $94 \%$ and $71 \%$ of the differences in behavior towards intent for both public and private professionals individually. The study recommended speeding up e-marketing implementation, the easiness of use and recompenses needs to be verified using divergent programs like video displays and workshops.

Tsekouropoulos et al. (2013) examined marketing and digital functions in rural agribusiness to categorize the commercial websites of the countryside organizations adopting the cluster analysis. Findings revealed that rural business can be differentiated in two clusters "more organized" business and "less organized" business. Besides, they spotted and portray the optimal group of rural agricultural businesses to be emulated as an example of improved marketing and digital functions.

Thomas et al. (2016) evaluated the relevance of social media as a means of agricultural information using Kesses District farmers investigated in Kenya. They made use of a descriptive survey on primary data. They recommended the establishment of information centers in the areas where farmers can be readily sourced for veritable information that will help improve their farming activities.

Fainos et al. (2014) examined the role of agricultural marketing on the empowerment of rural farmers in Masvingo Province, Zimbabwe. Data gathered from 361 farmers who are specialists in maize, groundnuts, small grain crops, and vegetable production revealed that the farmers lack access to market information given their use of traditional means of gathering information. They, therefore, recommended the government's improvement of training centers to provide knowledge to rural farmers as well as the establishment of a marketing board to harmonize marketing activities.

Rebekka and Saravanan (2015) researched on access and extent of use of ICTs in agriculture and rural development by the tribal farmers in Meghalaya State of North-East India. The study sampled 120 farmers randomly drawn between November 2013 and May 2014. The research findings revealed that a vast number of farmers have access to mobile phones and other telephones.

Venkatesh and Swetha (2018) to provide insight into the influences of digital marketing on rural marketing by using the Chickballapura region revealed that poor farmers' viewpoints on digital marketing, therefore, making some propositions regarding rural marketing development through digitalization.

\section{METHODOLOGICAL ASPECTS}

\subsection{Data and variable specification}

The study used Nigeria annual data which covers the period 1995 to 2018 and sourced from the World Development Indicator of the World Bank. This is because data showed that the use of mobile phones began in 1993 in Nigeria while the mobile phone was from 1996. This may not be common in the rural areas and among the farmers at this earlier time but since our time series data on the use of ICT in rural Nigeria is not available, we decided to use the national data. The quantitative estimation was done using the E-views 9.0 version of the econometric software. Data on Agriculture value added (constant 2010 US\$) was used as a measure for rural transformation. This is because the rural sector is characterized by more of agricultural activities. Digital marketing and ICT are our major variables of concern that were captured using the individuals' use of the internet (\% of the population) and mobile cellular subscriptions (per 1000). Agricultural technology was captured by agricultural equipment (proxy by tractors per $100 \mathrm{sq} \mathrm{km}$ of arable land). Physical capital was captured by agricultural land (\% of total land area). Human capital represented by the 
active agricultural labour force, and education captured by gross enrollment into at least the secondary and primary levels. Rainfall is also added as it is a major component of agricultural output level.

\subsection{Model}

To achieve the goal of this study of determining the impact of digital marketing on rural transformation, we employed the Cobb-Douglas production function following the studies of Chavula (2013); Olaniyi (2018) and Ogbeide et al. (2019). The rural sector is transformed when there is an increase in the value-added of agriculture. Agricultural output is a function of physical capital (P), Human capital $(\mathrm{H})$, and agricultural technology $(\mathrm{T})$. Our Cobb-Douglas production function is given as:

$$
Y=A T^{\beta} H^{\alpha} P^{\delta}
$$

Where $\beta \delta \alpha$ are constant, $\mathrm{A}$ is the Hichs-neutral productivity level which is a function of the level of ICT (technology) and digital marketing can only be achieved by the use of ICT facilities. Taking a linear form of the model. We modified the production function in (1) by adding (R) rainfall, since production in the agricultural sector relies highly on the amount of the country's rainfall and econometrically, we have:

$$
\log Y=\log A+\beta \log (T)+\alpha \log (H)+\delta(P)+\eta \log (R)+\mu
$$

Expanding the model to include all variables for the study and taking the log $\ln$ of equation 2 becomes,

$\log Y=\theta_{0}+\theta_{1} I N T+\theta_{2} M B+\theta_{3} A G L+\theta_{4} P G E N R+\theta_{5} S G E N R+\theta_{6}$ Agm $+\theta_{7} R+\theta_{8}$ Aloan $+\theta_{9} L a+$ $\mu \ldots$ (3)

Where:

$\mathrm{Y}=$ rate of rural transformation captured by agriculture value-added

INT $=$ internet usage

$\mathrm{MB}=$ use of mobile phones

$\mathrm{AGL}=$ agricultural labour force

PGENR = primary gross enrollment rate,

SGENR = secondary gross enrollment rate,

$\mathrm{Agm}=$ agriculture machine captured by a tractor

$\mathrm{R}=$ amount of rainfall

Aloan = agricultural loan,

$\mathrm{La}=$ agriculture land $(\%$ of total land area)

ei $=$ error term

\subsection{Estimation method}

The study used the Ordinary Least Square method of estimation given its ability to provide BLUE estimates.

\subsection{Estimation procedure}

The correlation among the variables was carried out to determine the presence of multicollinearity. Thereafter, the stationarity state of the variables were determined to prevent spurious result. Other diagnostic tests were also carried out. 


\section{EMPIRICAL PRESENTATION AND INTERPRETATION RESULTS}

\subsection{Correlation}

To determine the presence of multicollinearity among the variables, we employed the correlation analysis was carried out on and the result presented in Table 1. The outcome showed that the internet (INT) and mobile use (MB) were positively correlated with the agricultural value-added (Y). The secondary was also found to be positively correlated with $\mathrm{Y}$ showing that education is needed for the effective use of internet and mobile for marketing and hence transforming the rural sector. Agricultural labour (AGL) and the gross primary enrollment rate were negatively correlated with Y. AGL and PGENR were also found to be negatively correlated with INT and MB. This suggests that a large number of AGL are not using INT and MB maybe because of the financial or low educational status of the rural areas. However, the policy implication of this study will be drawn from a multivariate regression analysis.

Table 1: Correlation matrix

\begin{tabular}{|c|c|c|c|c|c|c|c|c|c|c|}
\hline & $\bar{Y}$ & INT & MB & \multicolumn{2}{|c|}{ PGENR SGENR } & AGL & AGM & $\overline{A L O A N}$ & LA & $\mathbf{R}$ \\
\hline$\overline{\mathrm{Y}}$ & 1 & & & & & & & & & \\
\hline INT & 0.817 & 1 & & & & & & & & \\
\hline MB & 0.812 & 0.801 & 1 & & & & & & & \\
\hline PGENR & -0.249 & -0.394 & -0.416 & 1 & & & & & & \\
\hline SGENR & 0.811 & 0.800 & 0.805 & -0.216 & 1 & & & & & \\
\hline AGL & -0.883 & -0.803 & -0.806 & 0.307 & -0.824 & 1 & & & & \\
\hline AGM & 0.812 & 0.729 & 0.777 & -0.026 & 0.831 & -0.803 & 1 & & & \\
\hline ALOAN & 0.789 & 0.807 & 0.851 & -0.360 & 0.790 & -0.804 & 0.656 & 1 & & \\
\hline LA & 0.327 & 0.120 & 0.119 & 0.520 & 0.193 & -0.272 & 0.564 & 0.087 & 1 & \\
\hline $\mathrm{R}$ & -0.446 & -0.490 & -0.508 & -0.050 & -0.603 & 0.499 & -0.356 & -0.493 & 0.048 & 1 \\
\hline
\end{tabular}

Source: Authors' computations using data on Eviews

\subsection{Unit root test}

The variable's order of integration varied using Kwiatkowski-Phillips-Schmidt-Shin (KPSS) test which has been found to correct some defects of the ADF. Table 2 revealed that all the variables were stationary after the first differencing, except PGENR and La which were seen to be $\mathrm{I}(0)$. With these various levels of integration among the variables, we employed the Autoregressive Distributed Lag Bound testing method of cointegration for the existence of cointegration among the variables.

Table 2: Results of KPSS unit root test

\begin{tabular}{lccccc}
\hline Variables & Levels & $\mathbf{5 \%}$ critical & $\mathbf{1}^{\text {st }}$ diff & $\mathbf{5 \%}$ critical & Remark \\
\hline Y & 0.8876 & 0.4630 & 0.1282 & 0.4630 & $\mathrm{I}(1)^{*}$ \\
INT & 0.4876 & 0.4630 & 0.4616 & 0.4630 & $\mathrm{I}(1)^{*}$ \\
MB & 0.8318 & 0.4630 & 0.2954 & 0.4630 & $\mathrm{I}(1)^{*}$ \\
AGL & 0.6601 & 0.4630 & 0.1294 & 0.4630 & $\mathrm{I}(1)^{*}$ \\
PGENR & 0.1966 & 0.4630 & & & $\mathrm{I}(0)^{*}$ \\
SGENR & 0.7940 & 0.4630 & 0.1054 & 0.4630 & $\mathrm{I}(1)^{*}$ \\
AGM & 0.5237 & 0.4630 & 0.4230 & 0.4630 & $\mathrm{I}(1)^{*}$ \\
R & 0.4822 & 0.4630 & 0.0560 & 0.4630 & $\mathrm{I}(1)^{*}$ \\
Alaon & 0.7734 & 0.4630 & 0.4137 & 0.4630 & $\mathrm{I}(1)^{*}$ \\
La & 0.2570 & 0.4630 & & & $\mathrm{I}(0)^{*}$ \\
\hline
\end{tabular}

Source: Authors' computations using data on Eviews 


\subsection{Co-integration test}

From the results of the unit root test, using the ARDL Bound testing was found more appropriate for testing the presence of cointegration among the variables. The result as shown in table 1 of the appendix revealed that the null hypothesis of no cointegration was accepted given F-stat of 2.09 which is below the 5\% critical value of the lower bound of 2.14 and 3.3 of the upper bound. Hence, we conclude that there is no cointegration among the variables. Given this outcome of the cointegration test, we resort to the Ordinary Least Square (OLS) estimation method in the estimation of the connectivity between digital marketing and rural transformation in Nigeria.

\subsection{Interpretation of OLS estimation}

In the investigation of the ability of digital marketing to bring about rural transformation, the OLS method of estimation was applied. The result is presented in Table 3.

Table 3: Long run results of OLS approach

\begin{tabular}{lccc}
\hline Variables & Coefficient & t-stat & Probability \\
\hline INT & 0.029 & 2.866 & 0.012 \\
MB & 0.000 & 1.032 & 0.319 \\
PGENR & 0.0002 & 0.045 & 0.964 \\
SGENR & 0.008 & 1.736 & 0.104 \\
AGL & 0.104 & 3.073 & 0.008 \\
AGM & 0.0002 & 8.774 & 0.000 \\
ALOAN & 0.0001 & 0.357 & 0.724 \\
LA & -0.008 & -0.544 & 0.594 \\
R & 0.001 & 0.569 & 0.578 \\
C & 15.962 & 7.237 & 0.000 \\
\multicolumn{1}{c}{$\mathrm{R}^{2}=0.892$} & DW $=1.742$ & F-Stat. $=216.741$ & Prob. $=0.000$ \\
\hline
\end{tabular}

Note: Dependent Var = Agricultural value-added $\log (\mathrm{Y})$

Source: Authors' computation using data on Eviews

Starting with the fitness of the model, the $\mathrm{R}^{2}$ confirmed the explanatory variables accounted for $89 \%$ of changes in agriculture value-added. The DW-statistics 1.74 showed absence of autocorrelation in the model and this was further firmed with the LM Serial Correlation Test of Breusch-Godfrey which showed an F-sat of 1.52 and Pro of 0.26 allowing us to accept the null hypothesis of no serial correlation hence, the model exhibits good fit. The presence of heteroskedasticity was also tested using the Breusch-Pagan-Godfrey. The F-stat of 1.09 made us take the null hypothesis of no heteroskedasticity. Hence, the result passed the conditions for the validity of OLS and our estimates are BLUE.

Analyzing the relationship and impact of the variables on rural transformation, the OLS result demonstrated that all the variables were positively related to agricultural value-added $(\mathrm{Y})$ in line with expectation except land (La). Specifically, the result showed that $1 \%$ increase in the use of the internet (INT), mobile phones $(\mathrm{Mb})$, gross enrollment at the primary and secondary levels of education, the agricultural labour force (AGL), credit to the agriculture (Aloan) and rainfall (R) results in $2.9 \%, 0.000024 \%, 0.02 \%, 0.84 \%, 10 \%, 0.02 \%, 0.15$ and $0.12 \%$ respectively increase in the rate of rural transformation all other variables held constant. The result showed that the use of mobile cellular subscriptions (MB) had the lowest magnitude on the rate of rural transformation. This can be attributed to the fact that MB became popular in Nigeria in early 2000 and given the cost of acquiring one, it may not be popularly used in their agricultural activities. The result also showed that an increase in the land (La) will result in a fall in rural transformation by $0.5 \%$. This is, however, contrary to expectation. 
On the substantial impact of the variables on the $\mathrm{Y}$, the result showed that internet (INT) and mobile (MB) usage, AGL and AGM had a substantial impact on our measure of rural transformation (Y) at a 5\% level of significance. This suggests that an increase in the use of digital marketing will result in rural transformation. This outcome is supported by some other studies. For instance, Abdulrahman et al. (2017) highly recommended ICT effective agriculture marketing to transform the rural sector, while Landes and Burfisher (2009) revealed that effective marketing increases agricultural production. Also, in line with our result of MB not having a substantial impact on rural transformation, Chavula (2013) found that mobile phones do not have a substantial impact. This is given the fact that infrastructures are usually very poor in rural areas where agriculture is predominant. For instance, assess to electricity is very low and the level of postprimary education is also very low and these are needed for effective digital marketing.

Therefore, increasing the educational rate in rural areas will facilitate the contribution of digital marketing. As was shown in the result, the PGENR and SGENR were not significant. Digital marketing needs an educational level beyond the primary level.

\section{POLICY COROLLARIES OF EMPIRICAL OUTCOME}

\subsection{Policy suppositions}

The study investigated if digital marketing could enhance rural transformation in Nigeria. The objective of the study was to examine the impact of digital marketing on the transformation of rural Nigeria. From the upshot of the empirical analysis, the following is policies recommended:

$>$ The use of the internet and mobile phones which were used to proxy digital marketing showed a positive relationship while the internet had a substantial impact on the transformation of rural Nigeria. Hence, we recommend that the infrastructural facilities for the effective use of these be increased in the rural area to increase the use of mobiles and the internet.

$>$ The agriculture labour force was found to have a positive and substantial effect on transforming rural areas. We thus recommend the increase in the agriculture labour force for the effective transformation of the rural area.

$>$ The levels of education were found not to have a substantial impact on rural transformation. This could be as a result of the low level of the post-primary level of education in the rural areas. Therefore, we recommend that educational advancement policies should go beyond the UBE to the secondary level of education and made compulsory in all the areas of the country.

\section{CONCLUSION}

Rural transformation is an intentional positive act of enhancing the development of the rural area and technology and effective marketing has been found as key instruments for shaping and transforming rural areas thereby increasing the level of development. Given that agriculture is predominant in rural areas, therefore, technology should be applied towards improving agricultural production. However, providing marketing devices that will increase the sales of agricultural output (digital marketing) is a vital tool for encouraging agricultural production. Results from the study revealed that digital marketing should be strongly encouraged and for the effective transformation of the Nigerian rural area. This was also consistent with other studies.

Funding: This study did not receive any specific financial support.

Competing Interests: The authors declared that they have no conflict of interests.

Contributors/Acknowledgement: All authors participated equally in designing and estimation of current research.

Views and opinions expressed in this study are the views and opinions of the authors, Asian Journal of Agriculture and Rural Development shall not be responsible or answerable for any loss, damage or liability, etc. caused in relation to/arising out of the use of the content. 


\section{References}

Abdulrahman, S., Abubakar, M. C., Suleiman, H. A., Mohammed, M., \& Idris, J. (2017). Application of ICT in agriculture: opportunities and challenges in developing countries. International Journal of Computer Science and Mathematical Theory, 5(1), 8-18.

Abdulsalam, Z, Akinola, M. O., \& Buwanhot, Y. Y. (2008). Problems and prospects of information and communication technologies application in agriculture in Nigeria. The Information Manager, 8(1), 1-10.

Alliance for affordability internet (2019). It helps me escape-2019 affordability report Nigeria impact story. Retrieved from https://a4ai.org/it-helps-me-escape-2019-affordability-reportnigeria-impact-story/.

Agwu, E. (2012). Generations X and Y's adoption of internet and internet banking in Nigeria: a qualitative study. International Journal of Online Marketing, 2(4), 68-81.

Chavula, H. (2013). Telecommunications development and economic growth in Africa. Information Technology for Development, 19(1), 1-19.

Fainos, C., Tendai, N., \& Munodawafa, N. (2014). The role of agricultural marketing on empowering rural farmers in Masvingo Province, Zimbabwe. European Journal of Business and Management, 6(3), 1-11.

Filani, M. O. (2000). Nigeria: The need to modify center-down development planning. In W. A. Stehr and D.R.P. Tailor (Ed.) Development from above or below. New York: John Wiley $\&$ Sons.

Igbenedion, V. I., \& Egwuelu, J. G. (2016). General entrepreneurship development. Progress P. E. Printing Associates, Agbor-Nigeria.

International Fund for Agricultural Development IFAD (2016). Rural Development Report 2016: Fostering inclusive rural transformation. Retrieved from https://www.ifad.org/

Landes, M. R., \& Burfisher, M. E. (2009). Growth and equity effects of agricultural marketing efficiency gains in India. Economic Research Report, 55959 U.S. Dept. of Agriculture, December. Retrieved from https://naldc.nal.usda.gov/download/37782/PDF.

Mbagwu, F. C, Benson, V. \& Onuoha, C. O. (2018). Challenges of meeting information needs of rural farmers through internet-based services: experiences from developing countries in Africa. A conference paper presented at the World Library and Information Congress: 84th International Federation of Library Association (IFLA) conference, Malaysia. Retrieved from

https://www.researchgate.net/publication/333718265_Challenges_of_meeting_informatio n n needs_of_rural farmers through_internet-

based_services_experiences from_developing_countries_in_Africa.

Mobile Report (2019). Key Nigerian facts country's economy showed positive growth. Retrieved from https://www.jumia.com.ng/mobile-report/.

Munyua, H., \& Adera, E. (2009). Emerging ICTs and their potential in revitalizing small-scale agriculture. Agricultural Information Worldwide, 2(1), 3-9.

National Agriculture Survey (2001). The Agriculture Production, Livestock Area and Land use data source, retrieved 6/6/2020 from https://www.statistics.gov.rw/datasource/75.

National Bureau of Statistics (2017). Nigeria Gross Domestic Product Report. Government of Nigeria, Nigeria.

National Bureau of Statistics (2018). Nigeria Gross Domestic Product Report. Government of Nigeria, Nigeria.

National Bureau of Statistics (2019). Nigeria Gross Domestic Product Report. Government of Nigeria, Nigeria.

Ndubuisi, E. (2017). How digital technology is changing farming in Africa. Retrieved from https://hbr.org/2017/05/how-digital-technology-is-changing-farming-in-africa

Nikola, M., Trendov, S. V., \& Meng, Z. (2019). Digital technologies in agriculture and rural areas. Food and Agriculture Organization of the United Nations, Rome. Retrieved from http://www.fao.org/3/ca4887en/ca4887en.pdf 
Nwobi, T. U. (2007). Cooperatives and rural financing. In E. E. Umebali (Eds.) Readings in Cooperative Economics and Management. Lagos: Computer Egde Publishers.

OECD (2010). African economic outlook 2010: Africa and its emerging partners. OECD Publishing, http://dx.doi. org/10.1787/aeo-2011-en.

Ogbeide, O. E. N., Ben, O., \& Ebhote, O. (2019). Accelerating agricultural productivity and marketing for rural transformation in Nigeria. Asian Journal of Agriculture and Rural Development, 9(2), 313-330.

Olaifa, T. P., \& Oyeniyi, J. O. (2014). Research library development in Nigeria: the role of information communication and technology (ICT). International Journal of Science and Research, 3(3), 256-259.

Olaniyi, E. (2018). Digital agriculture: mobile phones, internet and agricultural development in Africa. MPRA paper 90359, University Library of Munich, Germany. Retrieved from https://ideas.repec.org/p/pra/mprapa/90359.html

Pande, N., \& Deshmukh, P. (2015). ICT: A path towards rural empowerment through telecommunication, egovernance, and e-agriculture. IBMRD's Journal of Management \& Research, 4(2), 47-54.

Ramli, S. A., Samah, B. A., Hassan, M. S., Omar, S. Z., Bolong, J., \& Shaffri, H. A. M. (2015). Potential benefits of ICT for youth agro-based entrepreneurs in Malaysia. Journal of Applied Sciences, 15(3), 411-414.

Rebekka, S., \& Saravanan, R. (2015). Access and usage of ICTs for agriculture and rural development by the tribal farmers in Meghalaya state of North-East India. Journal of Agricultural Informatics, 6(3), 24-41.

Russon, M. (2020). How internet access is improving in Nigeria. Business reporter, BBC News. Retrieved from https://www.bbc.com/news/business-51377955.

Seyed, J. A., Mohammad, S. A., Ahmad, S. A., \& Jhalukpreya, S. R. (2016). Adoption of agricultural e-marketing: application of the theory of planned behavior. Journal of International Food \& Agribusiness Marketing, http://dx.doi.org/10.1080/08974438.2016.1229242.

Singh, K. M., Kumar, A., \& Singh, R. K. P., (2015a). Role of Information and Communication Technologies in Indian Agriculture: An Overview. 1 -12. Available at SSRN 2570710.

Singh, V., Sankhwar, S., \& Pandey, D. (2015b). The Role of Information Communication Technology (ICT) in Agriculture. Global Journal of Multidisciplinary Studies, 3(4), 2-10.

Thomas, K., Michael, O., \& Silahs, C. (2016). Impact of social media on agricultural extension in Kenya: a case of Kesses district. International Journal of Agricultural Extension and Rural Development Studies, 3(1), 30-36.

Tolulope, K., Kayode, A., \& Edwin, M. (2015). Application of ICT to Agriculture as a panacea to unemployment in Nigeria. International Journal of Advanced Multidisciplinary Research and Review, 3(4), 26-48.

Tsekouropoulos, G., Koliouska, C., \& Andreopoulou, Z. (2013). Marketing and digital functions in rural agribusiness: A Case of Classification. Journal of Marketing Vistas, 3(2), 1-10.

Trading Economics (2020). Nigeria-rural population. Retrieved from https://tradingeconomics.com/nigeria/rural-population-percent-of-total-population-wbdata.html.

Venkatesh, B. B. R., \& Swetha, M. R. (2018). A study on venues for digital marketing in rural areas with respect to Chickballapura District. International Journal of Advanced in Management, Technology and Engineering Sciences, 8(1), 1-13.

Wireless Intelligience (2011). Wireless Intelligence: $3 G$ comes of age in the Americas. Retrieved from https://www.gsma.com/latinamerica/wireless-intelligence-3g-comes-of-age-in-theamericason.

Yimer, M. (2015). The Role of ICT for good governance and agricultural development in Ethiopia: local evidence from Southern Ethiopia. International Journal of Political Science and Development, 3(1), 30-39. 


\section{Appendix}

Table 1: Results of cointegration test using bound testing

Null Hypothesis: No long-run relationships exist

Test Statistic

Value

F-statistic

1.862017

k

Critical Value Bounds

Significance

$10 \%$

I0 Bound

1.88

I1 Bound

$5 \%$

2.14

2.99

$2.5 \%$

2.37

3.3

$1 \%$

2.65

3.6

3.97 